\title{
The Impact of Mergers on the Financial Performance of Jordanian Public Shareholding Companies
}

\author{
Maha AYOUSH ${ }^{1}$, Hesham RABAYAH ${ }^{2}$, Thaer JIBREEL ${ }^{3}$ \\ Received: August 01, 2020 Revised: September 06, 2020 Accepted: September 10, 2020
}

\begin{abstract}
This study examines the impact of mergers on the financial performance of the Jordanian public shareholding companies. The study employs data collected for a sample of 10 Jordanian non-financial public firms that were engaged in legal horizontal merger deals between 2000 and 2013. The data was collected from the published annual financial reports of the merging companies and comparative companies for three years before the merger and three years after the merger. Event study methodology was applied to examine the data. Four measures of financial performance (FP) were used, which are return on assets (ROA), return on equity (ROE), earnings per share (EPS), and net profit margin (NPM). Two methods were used in the analysis - the change model and the intercept model using financial performance raw data and industry-adjusted data. The findings in general showed no significant impact of mergers on the financial performance of merging firms using the change model. However, by using the intercept model, significant impact of mergers on the financial performance was found on the sample of the study. The significant impact was found for mergers on the raw ROE of the merging firms, and on the ROA and NPM of the industry-adjusted firms.
\end{abstract}

Keywords: Change Model, Financial Performance, Intercept Model, Jordanian Public Shareholding Companies, Mergers

JEL Classification Code: G34, L25, M41

\section{Introduction}

The world has witnessed great developments in the recent period, especially in economics, politics, and other areas, which had significant impacts on the occurrence of radical changes in economic institutions, leading them to confront these changes by developing operations and performance (Ayoush, 2011). Among these changes is the subject of mergers. Mergers generally are described as a combination

${ }^{1}$ First Author and Corresponding Author. Assistant Professor, Department of Accounting, Faculty of Business, Al-Zaytoonah University of Jordan, Jordan [Postal Address: Queen Alia Airport St 594, Amman, Jordan] E-mail: Maha.Ayoush@zuj.edu.jo

${ }^{2}$ Assistant Professor, Department of Civil and Infrastructure Engineering, Faculty of Engineering and Technology, Al-Zaytoonah University of Jordan, Jordan. E-mail: h.ahmad@zuj.edu.jo

${ }^{3}$ Department of Accounting, Faculty of Business, Al-Zaytoonah

University of Jordan, Jordan. E-mail: thaer.j.1994@gmail.com

(C) Copyright: The Author(s)

This is an Open Access article distributed under the terms of the Creative Commons Attribution Non-Commercial License (https://creativecommons.org/licenses/by-nc/4.0/) which permits unrestricted non-commercial use, distribution, and reproduction in any medium, provided the original work is properly cited. of two companies seeking to achieve multiple business and strategic objectives (Sudarsanam, 2010). In a merger, two firms integrate their assets and activities and pool their resources to create a new legal entity and accomplish common goals.

Amounts and volumes of mergers around the world have reached unprecedented levels today. The main reasons are attributed to the global financial crisis and, then, the need to create large entities that can compete in search of growth and profit, as well as increased capital flows across national borders of different countries due to economic reform programs and market liberalization in developing countries (Al-Dabbas, 2012). Other reasons for the increase in the number of mergers may be attributed to the high level of globalization and risk diversification as well as achieving a competitive advantage over the rivals (Kumar \& Bansal, 2008).

The issue of the merger of economic institutions is one of the major topics in the accounting and finance fields, and is important for the stakeholders, especially the shareholders who always expect the management of the company to enhance the value of the equity by raising the profits achieved. This goal is accomplished either 
through internal business enhancement or through external enhancement, which is generally maintained through merger or acquisition.

Therefore, this study investigates the impact of mergers on the financial performance of the Jordanian public shareholding companies. More specifically, this study seeks to provide insights about the merger strategy in Jordan, and whether it is conducive to improved performance for the companies. The performance is measured using different instruments, which are return on assets (ROA), return on equity (ROE), earnings per share (EPS), and net profit margin (NPM).

The main objectives of this research are to examine and investigate mergers in Jordan and provide an in-depth analysis on the impact of merger deals on the financial performance of Jordanian public shareholding companies. This will be achieved by comparing pre- and post-merger performance of these Jordanian firms using different performance measures and compared with other companies in the same sector that did not merge.

The study will therefore focus on the examination of four key measures of the Jordanian public shareholding companies:

[1]. The impact of mergers on ROA.

[2]. The impact of mergers on ROE.

[3]. The impact of mergers on EPS.

[4]. The impact of mergers on NPM.

The examination in this research will endeavor to provide strategic plans as well as a transparent forum for businesses planning to participate in merger transactions in such a way as to help them decide whether or not to merge. The findings will have strong implications for executives, shareholders as well as decision-makers and policy-makers as to whether mergers in Jordan should be actively promoted or discouraged.

Findings from the study could also shed some light for academics as well as decision-makers and policymakers in formulating better strategies to optimize the allocation of resources in a way that benefits both the company and the economy as a whole. In addition, this study will be a contribution to the literature, since to the best of the authors' knowledge, no such research was carried out in Jordan before, and therefore there has been no empirical evidence on the impact of mergers on the financial performance of merging firms in the country taking into consideration the industry-adjusted performance. Moreover, four different measures are used to analyze the effect of mergers on merging firms' financial performance and two different approaches are applied. This will add to the empirical evidence related to some theories such as synergy theory and diversification theory.

\section{Literature Review}

Previous studies over the years have presented several explanations for merger strategies by examining the different motives behind mergers in general as a way of growth. In general, achieving synergy has been the most cited motivation for mergers in previous studies. However, there have been other motivations for the merger strategy such as increasing market power, managerial reasons, diversification and tax motives (De Pamphilis, 2008). According to Sheikh et al. (2015), merger activities have emerged in the form of waves. These waves have risen up during economic prosperity, mainly with the availability of cheap credit, while they have declined during global crises to return to raising after the adaptation and changing of the companies' strategies (Sheikh et al., 2015).

Overall, the previous literature conceptually classified mergers into three main groups, consisting of horizontal mergers, vertical mergers, and mergers of conglomerates. Horizontal merger means the combination of two firms that are operating in the same line of business and competing in the same industry and market in order to achieve synergy and greater market power (Gaughan, 2007). Vertical merger means the combination of firms from different parts of the value chain, where the merger occurs between the firm and its consumer or supplier through forward and backward integration along the supply chain (Gaughan, 2007). This type of merger forms a new company that carries out the entire production process and takes advantage of the cost reduction and gaining economies of scope (Al-Dabbas, 2012). Conglomerate mergers means the merger of companies that operate in various industries and lines of business with unrelated operations to diversify and distribute their risk and increase economies of scope (Gaughan, 2007). In Jordan, the permitted mergers are only horizontal and vertical mergers since conglomerate mergers are not allowed according to Article (222) of the Jordanian Companies Law no. 22 for the year 1997.

From another point of view, mergers can also be characterized as friendly or hostile depending on the target's mood. If the board of the target firm agrees to engage in the merger transaction, then it is called friendly takeover. On the other hand, if the board of the target firm rejects the merger transaction when it takes place, then it is called hostile transaction (UNCTAD, 2000). Another classification for mergers could be either domestic or cross-border based on the target country. Domestic mergers occur when the acquirer and the target firms operate in the same country, whereas cross-border mergers occur when the acquirer and the target firms operate in different countries (UNCTAD, 2000). In this study, the examination is conducted for domestic mergers only. 
Table 1 summarizes major studies that are closely related to this study. These have yielded various results about the impact of mergers on the performance of companies. Some of them concluded that mergers had a positive impact on the performance (Siqueira et al., 2017; Yanan et al., 2016), whilst others found that mergers had negative impact (Bianconi \&
Tan, 2019; Lakstutiene et al., 2015). However, still others have shown no significant impact on the performance of companies (Pervan et al., 2015; Abu-Abbas et al., 2014). Therefore, those findings show that there are still inconsistencies over the results about the impact of mergers on firms' performance, which needs more examination about this strategy.

Table 1: Summary of Major Previous Studies Examining Mergers

\begin{tabular}{|c|c|c|c|}
\hline Authors & Sample & Research Variables & Results \\
\hline $\begin{array}{l}\text { Al-Hroot } \\
\text { et al. }(2020)\end{array}$ & $\begin{array}{l}\text { One merger between two } \\
\text { banks in } 2005 .\end{array}$ & $\begin{array}{l}\text { Performance-related financial ratio } \\
\text { groups that are expressed by leverage, } \\
\text { liquidity, efficiency, and cash flow ratio, } \\
\text { for two periods: four years pre-merger } \\
\text { and four years post-merger for the } \\
\text { period from } 2001 \text { to } 2009 \text {. }\end{array}$ & $\begin{array}{l}\text { Insignificant improvement in the ratios, } \\
\text { except for the leverage ratios that improved } \\
\text { significantly. }\end{array}$ \\
\hline Koo (2020) & $\begin{array}{l}452 \text { cases for the } \\
\text { CAR and } 498 \text { cases for } \\
\text { the analysis of acquisition } \\
\text { premiums, }\end{array}$ & $\begin{array}{l}\text { The study addresses different roles } \\
\text { of target and acquirer advisors, and } \\
\text { explores their influences on the } \\
\text { cumulative abnormal returns (CAR) } \\
\text { and acquisition premiums. }\end{array}$ & $\begin{array}{l}\text { The target advisor's positive association with } \\
\text { CAR and acquirer advisor's positive association } \\
\text { with acquisition premiums. This study indicates } \\
\text { the target advisor's positive contribution } \\
\text { to the success of acquisition process and } \\
\text { performance, and acquirer advisor's negative } \\
\text { influence on the deal progress. }\end{array}$ \\
\hline $\begin{array}{l}\text { Bianconi and } \\
\text { Tan (2019) }\end{array}$ & $\begin{array}{l}65,521 \text { global deals for } \\
\text { the period } 2000-2010 .\end{array}$ & $\begin{array}{l}\text { Firm value measured by enterprise } \\
\text { value (EV) over earnings before } \\
\text { interest, tax, depreciation and } \\
\text { amortization (EBITDA). } \\
\end{array}$ & $\begin{array}{l}\text { The results reflect a net decrease in EV/ } \\
\text { EBITDA over the medium-run, whereas an } \\
\text { increase in the firm value at the time of the } \\
\text { deal. }\end{array}$ \\
\hline $\begin{array}{l}\text { Al-Hayek } \\
(2018)\end{array}$ & $\begin{array}{l}\text { JHordanian target case } \\
\text { study for the period 2002- } \\
2016 .\end{array}$ & $\begin{array}{l}\text { Energy sales, energy purchase cost, } \\
\text { other operating revenues, other } \\
\text { revenues, operating expenses, other } \\
\text { expenses, earning per share. }\end{array}$ & $\begin{array}{l}\text { Statistically significant differences in all the } \\
\text { variables examined except the variable } \\
\text { other expenses, which showed no significant } \\
\text { difference. }\end{array}$ \\
\hline $\begin{array}{l}\text { Jallow et al. } \\
\text { (2017) }\end{array}$ & $\begin{array}{l}\text { Forty UK companies in } \\
\text { year } 2011 .\end{array}$ & $\begin{array}{l}\text { Return on assets, return on equity, } \\
\text { earnings per share and net profit } \\
\text { margin. }\end{array}$ & $\begin{array}{l}\text { Merger and Acquisition }(M \& A) \text { have a } \\
\text { significant impact on return on assets, return } \\
\text { on equity and earning per share. }\end{array}$ \\
\hline $\begin{array}{l}\text { Siqueira et } \\
\text { al. }(2017)\end{array}$ & $\begin{array}{l}\text { Sugar and alcohol } \\
\text { industry in Brazil in } 2014 .\end{array}$ & $\begin{array}{l}\text { Sales Revenue, Operating Expenses, } \\
\text { Sales Expenses, General and } \\
\text { Administrative Expenses, Net Income, } \\
\text { Return on Assets, Return on Net } \\
\text { Equity, and Return on Sales. }\end{array}$ & $\begin{array}{l}\text { A significant decrease in operating expenses } \\
\text { and non-significant gains in other indicators. }\end{array}$ \\
\hline $\begin{array}{l}\text { Yanan et al. } \\
(2016)\end{array}$ & $\begin{array}{l}\text { One hundred companies } \\
\text { in the United States of } \\
\text { America. }\end{array}$ & $\begin{array}{l}\text { Return on equity, earnings per share, } \\
\text { net profit margin and sales growth. }\end{array}$ & $\begin{array}{l}\text { M\&A increased the profitability and enlarged } \\
\text { their market share. }\end{array}$ \\
\hline $\begin{array}{l}\text { Al-Hroot } \\
(2016)\end{array}$ & $\begin{array}{l}\text { Seven industrial } \\
\text { Jordanian companies for } \\
\text { the period 2000-2014. }\end{array}$ & $\begin{array}{l}\text { Profitability, efficiency, liquidity, } \\
\text { leverage and market prospect } \\
\text { performance. }\end{array}$ & $\begin{array}{l}\text { Overall financial performance improved } \\
\text { insignificantly in post-merger period. }\end{array}$ \\
\hline $\begin{array}{l}\text { Lakstutiene } \\
\text { et al. (2015) }\end{array}$ & $\begin{array}{l}\text { Nine Lithuanian } \\
\text { companies during the } \\
\text { period of } 2008-2010 .\end{array}$ & $\begin{array}{l}\text { Return on assets, return on equity and } \\
\text { net profit margin. }\end{array}$ & Profitability decreased after the acquisition. \\
\hline $\begin{array}{l}\text { Pervan et al. } \\
(2015)\end{array}$ & $\begin{array}{l}116 \text { target companies in } \\
\text { Croatia between } 2008 \\
\text { and } 2011 .\end{array}$ & $\begin{array}{l}\text { Return on assets, return on equity and } \\
\text { profit margin. }\end{array}$ & $\begin{array}{l}\text { No statistically significant differences } \\
\text { between pre-merger and post-merger target } \\
\text { companies' profitability. }\end{array}$ \\
\hline $\begin{array}{l}\text { Abu-Abbas } \\
\text { et al. }(2014)\end{array}$ & $\begin{array}{l}\text { Two industrial companies } \\
\text { in Jordan for the years } \\
2007 \text { and } 2008 \text {. }\end{array}$ & $\begin{array}{l}\text { Liquidity, profitability and financial } \\
\text { leverage ratios. }\end{array}$ & $\begin{array}{l}\text { Mixed results for liquidity and leverage ratios, } \\
\text { whereas negative results for profitability } \\
\text { ratios. }\end{array}$ \\
\hline
\end{tabular}


This research will therefore shed light on the effect of mergers on the financial performance of public shareholding firms in Jordan. This research will also seek to investigate some of the problems in a way that varies in the following ways from the previous studies: it will examine the impact of mergers on the financial performance of public merging firms in Jordan, in an attempt to fill a gap in the literature. In addition, the analyses conducted in this research applied the accounting-based approach by using methodological benchmarks and several measures and techniques.

\section{Research Samples and Methods}

\subsection{Data Sample}

The study population consists of non-financial public shareholding companies who were engaged in legal mergers for the period 2 to 2013. The final study sample after filtration yielded ten companies. The required data of the study was collected from Amman Stock Exchange using published annual statements of the merging and benchmark companies for three years before the merger and three years after the merger.

Several aspects must be accounted for the scope of this study:

[1]. The sample examined includes non-financial Jordanian public shareholding companies listed on Amman Stock Exchange.

[2]. The study contains ten companies participating in mergers during the years 2000 to 2013 and utilizes data for the period spanning from 1997 until 2016 covering three years prior to the first merger and three years after the last merger.

[3]. The study focuses on legal mergers only and excludes legal unification (union) and acquisitions because they need an independent study.

[4]. Non-merging companies from the same industry of the merging firms and similar to their size measured by total assets in year -1 are also included in the examination as benchmarks in order to construct the industry-adjusted sample.

\subsection{Research Methodology}

Two key approaches can be used to analyze mergers transactions: one is the stock-market approach and the other is the accounting-based approach (Tuch \& O'Sullivan, 2007). The second approach, the accounting-based approach, was used in this study to investigate the impact of mergers on the financial performance of merging public companies in Jordan. Two samples of data depending on raw financial performance and industry-adjusted performance were tested, which were also used in previous studies (Francis et al.,
2008; Selcuk \& Yilmaz, 2011; Healy et al., 1992; Adedeji \& Ayoush, 2017).

In this research, the accounting-based approach was used to determine whether there are any change or progress in merging firms' financial performance three years after the merger compared to three years before the merger using the change model. In addition, the intercept model was applied by regressing merging firms' mean post-merger performance to mean pre-merger performance taking into consideration the effect of the size of assets, as shown in Equation 1. Previous studies proved that the size of firms may have an effect on the post-merger financial performance (Filipovic, 2012).

$$
\text { FPpost }=\alpha 0+\alpha 1 * \text { FPpre }+\alpha 2 * \text { Fsize }+\varepsilon
$$

FPpost $=$ Mean post-merger financial performance of merging firms.

FPpre $=$ Mean pre-merger financial performance of merging firms.

Fsize $=$ Firm size as the natural logarithm of the total assets.

$\alpha 0=$ Represents the changes in financial performance of merging firms.

$\alpha 1=$ Represents the relation between pre-merger financial performance and post-merger financial performance of merging firms.

$\alpha 2=$ Represents the relation between size and postmerger financial performance of merging firms.

Four different financial performance measures were used to analyze the effect of mergers on merging firms' financial performance. These measures include ROA, ROE, EPS, and NPM. The examinations would investigate whether there is any significant difference between pre- and post-merger periods in financial performance. The process of measuring study variables is carried out according to the following mathematical equations:

$$
\text { Return On Assets }(\text { ROA })=\text { Net Income } / \text { Total Assets }
$$

Return On Equity $(\mathrm{ROE})=$ Net Income / Total Shareholders' Equity

Earnings Per Share (EPS) $=$ Net Income/ Numbers of Ordinary Shares Outstanding

Net Profit Margin $($ NPM $)=$ Net Income / Net Sales

In the examination of this study two samples were created using the raw financial performance data of the merging 
companies in the first sample, and the difference of the financial performance data of the merging and the merging peers in the second sample. To achieve the goals of this study the researchers analyzed the financial statements data of the two samples using the following metrics and statistical tools:

[1]. Descriptive statistics measures, which included Mean, Standard deviation, Max value, and Min value.

[2]. Pre-tests as the normal distribution test via the skewness coefficient.

[3]. T-test for Paired samples when there is a normal distribution condition for the study data and Wilcoxon test which is one of the non-parametric tests when there is no normality distribution condition to know the statistical differences between the financial performance before and after the merger.

[4]. Multiple linear regression test to know the effect of financial performance before merger on financial performance after merger taking into consideration the effect of the firm size.

Figure 1 summarizes the procedure followed in applying the methodology.

\subsection{Hypotheses}

The main aim of the research is to test the following hypotheses:

The main hypothesis: Mergers have a statistically significant impact on the financial performance of the Jordanian public shareholding companies.

The sub-hypotheses:

H1: Mergers have a statistically significant impact on the return on assets (ROA) of the Jordanian public merging firms.

H2: Mergers have a statistically significant impact on the return on equity (ROE) of the Jordanian public merging firms.

H3: Mergers have a statistically significant impact on the earnings per share (EPS) of the Jordanian public merging firms.

H4: Mergers have a statistically significant impact on the net profit margin (NPM) of the Jordanian public merging firms.

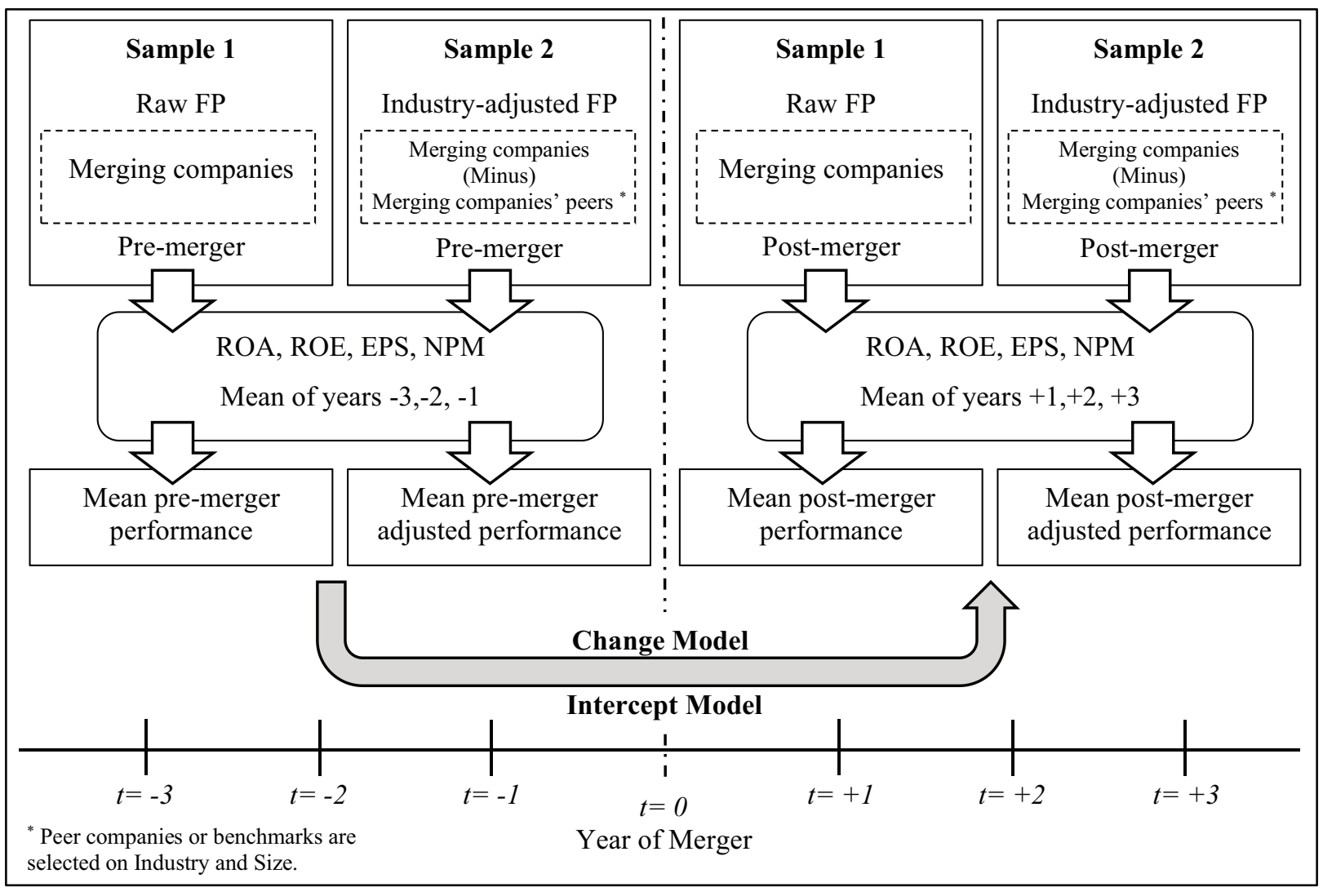

Figure 1: Methodology Applied to Measure Changes in Financial Performance of Merging Companies 


\section{Results and Discussion}

In this research, the financial indicators adopted (ROA, ROE, EPS, and NPM) for each of the merging companies' raw performance data and the industry-adjusted financial performance data were collected for three years before and after the merger, and the descriptive statistics were applied. The descriptive statistics results for all the studied merging and benchmark companies are shown in Table 2.

The size of the companies was measured by the natural logarithm of the total assets. Table 3 shows the mean, the standard deviation, and the largest and lowest values of the variable of the assets size.

Table 4 indicates the values of the Skewness coefficients, as if the values range between (-1) and (1) this indicates that the data is distributed normally. The table indicates the normality of distribution before and after merger for NPM variable for the merging companies' raw data, and ROA variable for the industry-adjusted sample. Thus the parametric methods will be used with these two variables. For the rest of the variables, they are not normally distributed and, thus, the Wilkoxon test will be used for the paired samples.

Table 2: Descriptive statistics of the study variables for the companies before and after merger

\begin{tabular}{|l|l|c|c|c|c|c|c|c|c|}
\hline \multirow{2}{*}{ Sample } & \multirow{2}{*}{ Statistical Measures } & \multicolumn{4}{|c|}{ Pre-Merger } & \multicolumn{4}{c|}{ Post-Merger } \\
\cline { 2 - 10 } & & ROA & ROE & EPS & NPM & ROA & ROE & EPS & NPM \\
\hline \multirow{4}{*}{$\begin{array}{l}\text { Merging } \\
\text { Companies }\end{array}$} & Mean & 1.13 & 5.12 & 0.051 & -8.29 & 2.96 & 3.26 & 0.07 & 8.31 \\
\cline { 2 - 10 } & Std. deviation & 9.78 & 6.37 & 0.156 & 55.5 & 3.58 & 6.00 & 0.14 & 8.90 \\
\cline { 2 - 10 } & Max value & 11.60 & 18.10 & 0.26 & 77.97 & 11.35 & 17.03 & 0.430 & 21.61 \\
\cline { 2 - 10 } & Min value & -23.52 & -4.25 & -0.29 & -108.12 & -1.97 & -6.44 & -0.07 & -5.35 \\
\hline \multirow{4}{*}{$\begin{array}{l}\text { Industry- } \\
\text { adjusted }\end{array}$} & Mean & -4.15 & 3.78 & 0.18 & 19.40 & -1.18 & -1.84 & -0.08 & -45.17 \\
\cline { 2 - 10 } & Std. deviation & 17.42 & 27.57 & 1.22 & 125.95 & 12.65 & 17.09 & 0.43 & 248.30 \\
\cline { 2 - 10 } & Max value & 24.53 & 70.74 & 3.54 & 321.32 & 20.84 & 20.05 & 0.47 & 162.82 \\
\cline { 2 - 10 } & Min value & -36.39 & -32.12 & -0.86 & -133.83 & -28.43 & -41.83 & -1.20 & -733.14 \\
\hline
\end{tabular}

Table 3: The company size variable for merging and benchmark companies

\begin{tabular}{|l|l|c|c|}
\hline Sample & Statistical Measures & Total Assets & Company Size \\
\hline \multirow{4}{*}{ Merging Companies } & Mean & $29,257,215.3$ & 16.73 \\
\cline { 2 - 4 } & Std. deviation & $25,397,842$ & 1.08 \\
\cline { 2 - 4 } & Max value & $71,687,088$ & 18.09 \\
\cline { 2 - 4 } & Min value & $3,845,086$ & 15.16 \\
\hline \multirow{5}{*}{ Benchmark Companies } & Mean & $22,408,404.3$ & 16.41 \\
\cline { 2 - 4 } & Std. deviation & $22,772,412.3$ & 1.09 \\
\cline { 2 - 4 } & Max value & $67,873,197$ & 18.03 \\
\cline { 2 - 4 } & Min value & $2,876,639$ & 14.87 \\
\hline
\end{tabular}

Table 4: Test of Normality results

\begin{tabular}{|l|c|c|c|c|c|c|c|c|}
\hline \multirow{2}{*}{ Sample } & \multicolumn{4}{|c|}{ Pre-Merger } & \multicolumn{4}{c|}{ Post-Merger } \\
\cline { 2 - 10 } & ROA & ROE & EPS & NPM & ROA & ROE & EPS & NPM \\
\hline Merging Companies & -1.96 & 0.803 & -0.866 & $-0.804^{*}$ & 1.34 & 1.05 & 2.06 & $-0.158^{*}$ \\
\hline Industry-adjusted & $-0.386^{*}$ & 1.61 & 2.71 & 1.50 & $-0.626^{*}$ & -1.40 & -1.98 & -2.83 \\
\hline
\end{tabular}

*Values showing data that is normally distributed. 
A test of statistical differences for the study variables of companies before and after the merger was conducted. Wilcoxon test was applied for variables that are not normally distributed, while paired t-test was conducted for variables that are normally distributed. The results of the tests were presented in Table 5 for the raw financial performance data of the merging companies and the industry-adjusted financial performance data. The results show no statistical differences between pre- and post-merger raw and industry-adjusted data for all the four studied financial performance measures.

The research tested the study hypotheses by applying multiple linear regression test. Table 6 lists the results of the multiple linear regression test for the two samples of merging raw financial performance and industry-adjusted data. The

Table 5: Results of Wilcoxon test and Paired T-test for merging companies

\begin{tabular}{|c|c|c|c|c|c|c|c|c|}
\hline Sample & Variable & Group & Number & Mean & Test Type & Z or $\mathrm{T}$ Value & Sig. & Differences source \\
\hline \multirow{8}{*}{ 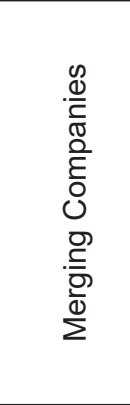 } & \multirow{2}{*}{ ROA } & Pre & 10 & 1.13 & \multirow{2}{*}{ Wilcoxon } & \multirow{2}{*}{-0.051} & \multirow{2}{*}{0.959} & \multirow{2}{*}{ No difference } \\
\hline & & Post & 10 & 2.96 & & & & \\
\hline & \multirow{2}{*}{ ROE } & Pre & 10 & 5.13 & \multirow{2}{*}{ Wilcoxon } & \multirow{2}{*}{-1.172} & \multirow{2}{*}{0.241} & \multirow{2}{*}{ No difference } \\
\hline & & Post & 10 & 3.26 & & & & \\
\hline & \multirow{2}{*}{ EPS } & Pre & 10 & 0.051 & \multirow{2}{*}{ Wilcoxon } & \multirow{2}{*}{-0.070} & \multirow{2}{*}{0.944} & \multirow{2}{*}{ No difference } \\
\hline & & Post & 10 & 0.077 & & & & \\
\hline & \multirow{2}{*}{ NPM } & Pre & 10 & -8.29 & \multirow{2}{*}{$\begin{array}{c}\text { Paired } \\
\text { t-test }\end{array}$} & \multirow{2}{*}{1.026} & \multirow{2}{*}{0.331} & \multirow{2}{*}{ No difference } \\
\hline & & Post & 10 & 8.31 & & & & \\
\hline \multirow{8}{*}{ 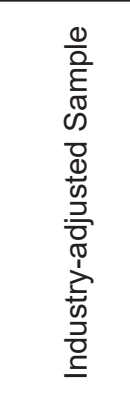 } & \multirow{2}{*}{ ROA } & Pre & 10 & -4.16 & \multirow{2}{*}{$\begin{array}{c}\text { Paired } \\
\text { t-test }\end{array}$} & \multirow{2}{*}{0.950} & \multirow{2}{*}{0.367} & \multirow{2}{*}{ No difference } \\
\hline & & Post & 10 & -1.18 & & & & \\
\hline & \multirow{2}{*}{ ROE } & Pre & 10 & 3.78 & \multirow{2}{*}{ Wilcoxon } & \multirow{2}{*}{-0.05} & \multirow{2}{*}{0.959} & \multirow{2}{*}{ No difference } \\
\hline & & Post & 10 & -1.84 & & & & \\
\hline & \multirow{2}{*}{ EPS } & Pre & 10 & 0.181 & \multirow{2}{*}{ Wilcoxon } & \multirow{2}{*}{-0.255} & \multirow{2}{*}{0.799} & No difference \\
\hline & & Post & 10 & -0.08 & & & & No amerence \\
\hline & & Pre & 10 & 19.40 & & & & \\
\hline & NPIVI & Post & 10 & -45.17 & Xon & -0.866 & 0.386 & ItTer \\
\hline
\end{tabular}

Table 6: Results of multiple linear regression tests

\begin{tabular}{|c|c|c|c|c|c|c|c|}
\hline Sample & Variable & $\mathbf{R}^{2}$ & F Value & Sig. & Equation & Sig. of FP & Sig. of $F_{\text {size }}$ \\
\hline \multirow{4}{*}{$\begin{array}{l}\text { Raw } \\
\text { Merging } \\
\text { Companies' } \\
\text { FP }\end{array}$} & ROA & 0.171 & 0.724 & 0.518 & $\begin{aligned} \mathrm{ROA}_{\text {post }}= & -0.086+0.153 * \mathrm{ROA}_{\text {pre }}+0.218 \\
& * \mathrm{~F}_{\text {size }}+\varepsilon\end{aligned}$ & 0.269 & 0.854 \\
\hline & ROE & 0.625 & 5.821 & $0.032^{*}$ & $\begin{aligned} \mathrm{ROE}_{\text {post }}= & 27.675+0.822{ }^{*} \mathrm{ROE}_{\text {pre }} \\
& +(-1.711){ }^{*} \mathrm{~F}_{\text {size }}+\varepsilon\end{aligned}$ & $0.011^{*}$ & 0.266 \\
\hline & EPS & 0.382 & 2.166 & 0.185 & $\begin{aligned} \text { EPS }_{\text {post }}= & -0.102+0.539 * \text { EPS }_{\text {pre }}+0.009 \\
& * F_{\text {size }}+\varepsilon\end{aligned}$ & 0.08 & 0.821 \\
\hline & NPM & 0.390 & 2.238 & 0.177 & $\begin{aligned} \mathrm{NPM}_{\text {post }} & =50.02+0.09 * \mathrm{NPM}_{\text {pre }}+(-2.44) \\
& { }^{*} \mathrm{~F}_{\text {size }}+\varepsilon\end{aligned}$ & 0.101 & 0.345 \\
\hline \multirow{4}{*}{$\begin{array}{l}\text { Industry- } \\
\text { adjusted } \\
\text { FP }\end{array}$} & ROA & 0.840 & 18.421 & $0.002^{*}$ & $\begin{aligned} \mathrm{ROA}_{\text {post }}= & 31.170+0.404{ }^{*} \mathrm{ROA}_{\text {pre }} \\
& +(-2.064){ }^{*} \mathrm{~F}_{\text {size }}+\varepsilon\end{aligned}$ & $0.001^{*}$ & 0.279 \\
\hline & ROE & 0.370 & 2.051 & 0.199 & $\begin{aligned} \mathrm{ROE}_{\text {post }}= & 39.899+0.252 * \mathrm{RO}_{\text {Epre }} \\
& +(-2.624) * \mathrm{~F}_{\text {size }}+\varepsilon\end{aligned}$ & 0.623 & 0.102 \\
\hline & EPS & 0.512 & 3.674 & 0.081 & $\begin{aligned} \mathrm{EPS}_{\text {post }}= & 2.023+0.218 * \mathrm{EPS}_{\text {pre }} \\
& +(-0.131) * \mathrm{~F}_{\text {size }}+\varepsilon\end{aligned}$ & 0.055 & 0.258 \\
\hline & NPM & 0.630 & 5.956 & $0.031^{*}$ & $\begin{aligned} \mathrm{NPM}_{\text {post }}= & -908.524+(-1.531){ }^{*} \mathrm{NPM}_{\text {pre }} \\
& +54.398 * \mathrm{~F}_{\text {size }}+\varepsilon\end{aligned}$ & $0.012^{*}$ & 0.334 \\
\hline
\end{tabular}

* Significant values less than 0.05 
regression models were significant for ROE of merging companies, and ROA and NPM of industry-adjusted data. In these models, the significance levels are less than 0.05 , and the value of the determination coefficient (R2) were at acceptable levels. For these three models, the significance level of the pre-merger financial performance was below 0.05 , while it is above 0.05 for the company size. For these models, the null hypotheses are rejected and the alternative hypotheses are accepted. So, in these models, the hypothesis that mergers have a statistically significant impact on the financial performance of Jordanian public merging firms is accepted. Also, for these models, the variable of the size of the company did not have statistically significant effects. The other models have levels of statistical significance greater than 0.05 , and thus the zero hypothesis is accepted that there is no effect for the pre-merger financial performance, on the post-merger financial performance in the Jordanian industrial companies.

\section{Conclusions}

The results using the change model for the sample of merging companies' raw FP data show that there are no statistically significant differences for the ROA variable between Jordanian public shareholding companies before the merger and after the merger. There are no statistically significant differences for the ROE variable between Jordanian public shareholding companies before the merger and after the merger. There are no statistically significant differences for the EPS variable between Jordanian public shareholding companies before the merger and after the merger. There are no statistically significant differences for the NPM variable between Jordanian public shareholding companies before the merger and after the merger.

Concerning the results for the industry-adjusted sample, there are no statistically significant differences for the industry-adjusted ROA variable before merger and after merger. There are no statistically significant differences for the industry-adjusted ROE variable before merger and after merger. There are no statistically significant differences for the industry-adjusted EPS variable before merger and after merger. There are no statistically significant differences for the industry-adjusted NPM variable before merger and after merger.

The results using the intercept model for the merging companies' raw FP data show that there is no statistically significant effect of the ROA variable before the merger on the ROA after the merger. There is a statistically significant positive effect of the ROE variable before the merger on the ROE after the merger. There is no statistically significant effect of the EPS variable before the merger on the EPS after the merger. There is no statistically significant effect of the NPM variable before the merger on the NPM after merger.

Concerning the results for the industry-adjusted sample, there is a statistically significant positive effect of the ROA variable before the merger on the ROA after the merger. There is no statistically significant effect of the ROE variable before the merger on the ROE after the merger. There is no statistically significant effect of the EPS variable before the merger on the EPS after the merger. There is a statistically significant negative effect of the NPM variable before the merger on the NPM after the merger.

Previous studies indicated that there were no statistical difference before the merger and after the merger, and others have confirmed that the financial ratios (ROA, ROE, and NPM) have decreased after the merger (Lakstutiene et al., 2015). The absence of the significant impact of the merger may be due to the economic slowdown in the Jordanian market. The results of this study were consistent with some previous studies (Aggarwal \& Garg, 2019; AL-Hroot, 2016; Yanan et al., 2016).

In light of the results of this study, the researchers recommend the following:

- Focusing on other variables when analyzing the expected impact of the merger in the future, since the results of the study indicated the absence of a statistically significant impact of the merger on some variables.

- Encouraging the Jordanian public shareholding companies to engage in mergers, in order to gain competitive advantage locally and regionally, and to face the surrounding conditions.

- Concentrating on the importance of monitoring and following up the merger operations and identifying the reasons behind the failure to achieve the merger goals or success.

- The necessity for public shareholding companies to disclose financial data accurately, to facilitate the work of decision makers and researchers in studying the impact of the merger on companies accurately and effectively.

The researcher also recommends the following work for future studies:

- Investigating more indicators in the Jordanian market, and provide strategies and policies that would help in judging merger as successful or unsuccessful.

- Studying the different market sectors separately in order to make comparisons among their results.

- Making a comparison study that concentrates on the difference between the impact of mergers on the financial performance in Jordan and other countries. 


\section{References}

Abu-Abbas, B. M., Daoud, M. R., \& Khalel, H. F. (2014). Do Mergers Affect the Financial Performance? Research Journal in Organizational Psychology and Educational Studies, 3(5), 378-387.

Adedeji, A., \& Ayoush, M. D. (2017). Are Cross Border Acquisitions More Profitable, or Do They Make Profit More Persistent, than Domestic Acquisitions? UK Evidence. International Business Research, 10(6), 178-188. https://doi.org/10.5539/ibr. v10n6p178

Aggarwal, P., \& Garg, S. (2019). Impact of Mergers and Acquisitions on Accounting-based Performance of Acquiring Firms in India. Global Business Review, 16(5), 15S-27S. https://doi.org/10.1177/0972150919852009

Al-Dabbas, M. M. (2012). The impact of the merger on the performance of companies and their profits. Journal of the Islamic University for Economic and Administrative Studies, 20(2).

Al-Hayek, M. A. (2018). The Effect of Acquisition on Income Statement Items in Acquired Company (Subsidiary Company)Case Study. International Journal of Economics and Finance, 10(5). https://doi.org/10.5539/ijef.v10n5p173

Al-Hroot, Y. A. (2016). The Impact of Mergers on Financial Performance of the Jordanian Industrial Sector. International Journal of Management \& Business Studies, 6(1), 9-13. https:// doi.org/10.13140/RG.2.1.4480.3602

Al-Hroot, Y. A., Al-Qudah, L. A., \& Alkharabsha, F. I. (2020). The Impact of Horizontal Mergers on the Performance of the Jordanian Banking Sector. Journal of Asian Finance, Economics and Business, 7(7), 49-58. https://doi.org/10.13106/ jafeb.2020.vol7.no7.049

Ayoush, M. D. (2011). Are cross-border mergers and acquisitions better or worse than domestic mergers and acquisitions? The UK evidence. PhD Thesis, University of Birmingham.

Bianconi, M., \& Tan, C. M. (2019). Evaluating the instantaneous and medium-run impact of mergers and acquisitions on firm values. International Review of Economics and Finance, 59, 71-87. https://doi.org/10.1016/j.iref.2018.08.005

De Pamphilis, D. (2008). Mergers, Acquisitions, and other restructuring activities (4th ed.), London, UK: Academic Press.

Filipovic, D. (2012). Impact of Company's Size on Takeover Success. Economic Research, 25(2), 435-444. https://doi.org/ 10.1080/1331677X.2012.11517516

Francis, B., Hasan, I., \& Sun, X. (2008). Financial market integration and the value of global diversification: Evidence for US acquirers in cross-border mergers and acquisitions. Journal of Banking \& Finance, 32(8), 1522-1540. https://doi. org/10.1016/j.jbankfin.2007.10.013

Gaughan, P. A. (2007). Mergers, Acquisitions, and Corporate Restructurings (4th ed.). Hoboken, NJ: John Wiley \& Sons.

Healy, P. M., Palepu, K. G., \& Ruback, R. S. (1992). Does corporate performance improve after mergers? Journal of Financial
Economics, 31(2), 135-175. https://doi.org/10.1016/0304405X(92)90002-F

Jallow, M. S., Masazing, M., \& Abdul Basit (2017). The Effects of Mergers and Acquisitions on Financial Performance: Case Study of UK Companies. International Journal of Accounting and Business Management, 5(1), 74-92. https://doi.org/24924/ ijabm/2017.04/v5.iss 1/74.92

Koo, J. S. (2020). How Do Advisors Influence Mergers and Acquisitions? An Analysis of Acquisitions in Japan. Journal of Asian Finance, Economics and Business, 7(7), 123-129. https:// doi.org/10.13106/jafeb.2020.vol7.no7.123

Kumar, S., \& Bansal, L. K. (2008). The Impact of Mergers and Acquisitions on Corporate Performance in India. Management Decision, 46(10), 1531-1543. https://doi. org/10.1108/00251740810920029

Lakstutiene, A., Stankevicieneb, J., Norvaisienec, R., \& Narbutiened, J. (2015). The Impact of Acquisitions on Corporate Performance Results during the Period of Economic Slowdown: Case of Lithuania. Procedia - Social and Behavioral Sciences, 213, 455-460. https://doi.org/10.1016/j.sbspro.2015.11.433

Pervan, M., Visic, J., \& Barnjak, K. (2015). The impact of M\&A on company performance: Evidence from Croatia. Procedia Economics and Finance, 23, 1451-1456. https://doi. org/10.1016/S2212-5671(15)00351-2

Selcuk, E. A., \& Yilmaz, A. A. (2011). The Impact of Mergers and Acquisitions on Acquirer Performance: Evidence from Turkey. Business and Economics Journal, 22, 1-8.

Sheikh, M. J., Ahmed, M., Arshad, Q., \& Shakeel, W. (2015). Mergers and Acquisitions as Vital Instruments of Corporate Strategy: Current and Historical Perspective. Journal of Asian Finance, Economics and Business, 2(1), 15-21. http://doi. org/10.13106/jafeb.2015.vol2.no1.15

Siqueira, P. H., Shikida, P. F., \& Cardoso, B. F. (2017). Impact of mergers and acquisitions on the performance of the sugar and alcohol industry in Brazil. Rivista di Economia Agraria, 72(2), 151-171. http://doi.org/10.13128/REA-22659

Sudarsanam, S. (2010). Creating Value from Mergers and Acquisitions: The Challenges (2nd ed.). Harlow, UK: Prentice Hall.

Tuch, C., \& O'Sullivan, N. (2007). The impact of acquisitions on firm performance: A review of the evidence. International Journal of Management Reviews, 9(2), 141-170. http://doi. org/10.1111/j.1468-2370.2007.00206.x

UNCTAD. (2000). World Investment Report 2000: Cross-Border Mergers and Acquisitions and Development. New York, NY: United Nations Conference on Trade and Development (UNCTAD).

Yanan, E. M., Hamza, S. M., \& Abdul Basit (2016). Impact of Merger and Acquisitions on Firms Financial Performance: A study on United States of America. International Journal of Accounting \& Business Management, 4(2), 159-169. http://doi. org/10.24924/ijabm/2016.11/v4.iss2/159.169 